\title{
Methanesulfonic Acid-driven New Particle Formation Enhanced by Monoethanolamine : A Computational Study
}

\section{Shen, Jiewen}

2019-12-17

Shen , J , Xie , H-B , Elm , J, Ma , F , Chen , J \& Vehkamaki , H 2019 , ' Methanesulfonic Acid-driven New Particle Formation Enhanced by Monoethanolamine : A Computational Study ' , Environmental Science \& Technology , vol. 53 , no. 24 , pp. 14387-14397 . https://doi.org/10.1021/acs.est.9

http://hdl.handle.net/10138/321265

https://doi.org/10.1021/acs.est.9b05306

unspecified

acceptedVersion

Downloaded from Helda, University of Helsinki institutional repository.

This is an electronic reprint of the original article.

This reprint may differ from the original in pagination and typographic detail.

Please cite the original version. 


\section{Methanesulfonic Acid-driven New Particle Formation}

2 Enhanced by Monoethanolamine: A Computational

3 Study

4 Jiewen Shen $^{\dagger}$, Hong-Bin $\mathrm{Xie}^{\dagger^{*}}$, Jonas Elm , Fangfang $\mathrm{Ma}^{\dagger}$, Jingwen Chen ${ }^{\dagger}$, Hanna

$5 \quad$ Vehkamäki ${ }^{\S}$

$6 \quad$ Key Laboratory of Industrial Ecology and Environmental Engineering (Ministry of

7 Education), School of Environmental Science and Technology, Dalian University of

8 Technology, Dalian 116024, China

9 Department of Chemistry and iClimate, Aarhus University, Langelandsgade 140, DK-

108000 Aarhus C, Denmark

11 Institute for Atmospheric and Earth System Research/Physics, University of Helsinki,

12 PO Box 64 (Gustaf Hällströmin katu 2a), FI-00014 Helsinki, Finland

Table of Contents (TOC)

14

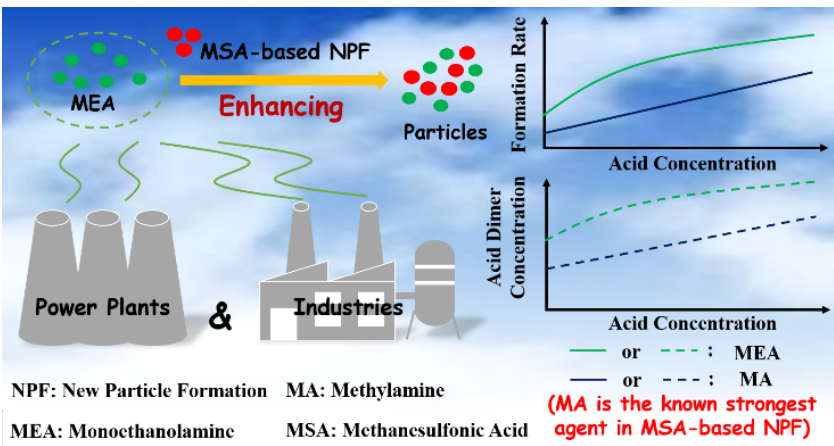

ABSTRACT. Amines are recognized as significant enhancing species on methanesulfonic acid (MSA)-driven new particle formation (NPF). Monoethanolamine (MEA) has been detected in the atmosphere and its concentration could be significantly increased once MEA-based post-combustion $\mathrm{CO}_{2}$ capture technology is widely implemented. Here, we evaluated the enhancing potential of MEA on MSA-driven NPF by examining the formation of MEA-MSA clusters using a combination of quantum 
21 chemical calculations and kinetics modeling. The results indicate that $-\mathrm{OH}$ group of

22 MEA can form at least one hydrogen bond with MSA or MEA in all MEA-containing

23 clusters. The enhancing potential of MEA is higher than that of the strongest enhancing

24 agent known so far, methylamine (MA), for MSA-driven NPF. Such high enhancing

25 potential can be ascribed to not only the higher gas-phase basicity, but also the role of

26 the additional $-\mathrm{OH}$ group of MEA in increasing the binding free energy by forming

27 additional hydrogen bonds. This clarifies the importance of hydrogen-bonding capacity

28 from the non-amino group of amines in enhancing MSA-driven NPF. The main growth

29 pathway for MEA-MSA clusters proceeds via the initial formation of the

30 (MEA) $)_{1}(\mathrm{MSA})_{1}$ cluster, followed by alternately adding one MSA and one MEA

31 molecule, differing from the case of MA-MSA clusters.

\section{INTRODUCTION}

33 New particle formation (NPF) represents the most important source of aerosol

34 particles in the atmosphere. ${ }^{1-4}$ Aerosol particles have a large influence on the global

35 climate and human health. ${ }^{3,5-9}$ A molecular-level understanding of NPF is crucial for

36 assessing the impacts of aerosols and developing optimal control strategies. ${ }^{10,11}$ There

37 is compelling evidence that sulfuric acid (SA) is a key NPF precursor in many

38 atmospheric environments. ${ }^{3,4,12-21}$ Many studies have revealed that atmospheric bases

39 (such as methylamine (MA), dimethylamine (DMA), trimethylamine (TMA) and

40 ammonia) and organic acids (such as aromatic acids, dicarboxylic acids and cis-pinonic

41 acid) can efficiently enhance SA-driven NPF. 1,3,5,12,22-28 However, SA-driven NPF 
alone still cannot explain the observed NPF rates globally.,5,7,21,29-32 Therefore, in recent years, great efforts have been made to better understand NPF by considering the involvement of other gaseous species.

Besides SA, methanesulfonic acid (MSA) has been identified as an important NPF precursor. ${ }^{29,33-36}$ MSA will play a more important role in NPF after the implementation of stricter regulations on $\mathrm{SO}_{2}$ emission of fossil fuel combustion. ${ }^{33,37}$ MSA is mainly derived from the oxidation of organosulfur compounds (OSCs) coming from oceans, agricultural activity, forest cover, and even from human exhalation. ${ }^{33,38}$ The atmospheric concentration of MSA is on the order of $10^{5}-10^{7}$ molecules $\mathrm{cm}^{-3}$, about 10 $100 \%$ of that of SA. ${ }^{39,40}$ Since the binary nucleation efficiency of $\mathrm{MSA}-\mathrm{H}_{2} \mathrm{O}$ is extremely low under typical atmospheric conditions, ${ }^{36}$ the contribution of MSA to NPF has been identified to highly depend on the enhancing effect of other species, primarily from atmospheric bases. ${ }^{29,41}$ Therefore, identifying the atmospheric bases with strong enhancing potential on MSA-driven NPF is important to fully understand the contribution of MSA to NPF.

Currently, the studied atmospheric bases for MSA-driven NPF include MA, DMA, TMA and ammonia, all of which have a significant enhancing effect. ${ }^{29,41}$ MA was found to be the strongest species to enhance MSA-driven NPF, ${ }^{41,42}$ in contrast to DMA which is the strongest one for SA-driven NPF. ${ }^{2,12}$ Relative to DMA (one N-H bond site) and TMA (no N-H bond site), the higher enhancing potential of MA is ascribed to its higher hydrogen-bonding capacity from the amino group (two N-H bonds sites) ${ }^{41}$ although its 

$\mathrm{kJ} \mathrm{mol}^{-1}$, for DMA $896.5 \mathrm{~kJ} \mathrm{~mol}^{-1}$ and for TMA $\left.918.1 \mathrm{~kJ} \mathrm{~mol}^{-1}\right) .{ }^{43}$ Relative to ammonia, it is ascribed to the higher basicity of MA (GB for ammonia is $\left.819.0 \mathrm{~kJ} \mathrm{~mol}^{-1}\right) .{ }^{41,43}$ This implies that both basicity and hydrogen-bonding capacity contribute to the enhancing potential of an atmospheric base on MSA-driven NPF. ${ }^{11,41,44,45}$ Therefore, atmospheric bases with stronger gas phase basicity and higher hydrogen-bonding capacity than MA could be even more efficient enhancing agents for MSA-driven NPF. Monoethanolamine (MEA) is a benchmark and widely utilized solvent in aminebased post-combustion $\mathrm{CO}_{2}$ capture (PCCC) technology and feed stock for the chemical and pharmaceutical industries. ${ }^{46-52}$ Previous studies have shown that a $\mathrm{CO}_{2}$ capture plant of MEA-based PCCC could potentially emit 80 tons MEA into the atmosphere for each 1 million tons of $\mathrm{CO}_{2}$ removed per year. ${ }^{53,54}$ Thus, once MEAbased PCCC technology has been implemented on a large-scale, it is likely that there will be significant discharges of MEA to the atmosphere from PCCC units. ${ }^{11,55}$ Even though PCCC technology is not yet used on a large scale, current global production of ethanolamines (including MEA, diethanolamine, and triethanolamine) could be surprisingly high. For instance, production of ethanolamines in America can reach up to $3 \times 10^{5}$ ton per year. ${ }^{52}$ MEA has been detected as a significant component of $\mathrm{PM}_{2.5}$

81 in various locations. ${ }^{56-58}$ In recent field measurement, it was found that MEA is one of 82 the two most abundant amines in $\mathrm{PM}_{2.5}$ in Shanghai. ${ }^{56}$ Compared to MA, MEA has 83 higher GB (896.8 $\left.\mathrm{kJ} \mathrm{mol}^{-1}\right)^{43}$ and higher hydrogen-bonding capacity due to its 
additional $-\mathrm{OH}$ group. ${ }^{11}$ Therefore, MEA could have a higher enhancing potential on MSA-driven NPF than MA. However, to the best of our knowledge, no previous study has addressed the participation of MEA in MSA-driven NPF and the role of additional hydrogen-bonding capacity from the non-amino group in enhancing MSA-driven NPF. Using quantum chemical methods and the Atmospheric Cluster Dynamics Code $(\mathrm{ACDC})^{59}$, we investigated the participation of MEA in the initial steps in MSA-driven NPF by examining the cluster formation between MEA and MSA. We have obtained the minimum free energy structures of the (MEA $)_{m}(\mathrm{MSA})_{n}(m=0-4, n=0-4)$ clusters and use the calculated thermodynamic data as input for ACDC simulations to obtain cluster formation pathways and rates. In addition, the effect of hydration on cluster formation kinetics was also considered.

\section{COMPUTATIONAL DETAILS}

Electronic Structure Calculations. The global minimum structures of the pure (MEA) $)_{1-4}$ clusters were taken from our previous study. ${ }^{11}$ A multi-step global minimum sampling scheme, which has been applied to study atmospheric cluster formation in previous studies, ${ }^{11,60-63}$ was employed to search for the global minima of the $(\mathrm{MEA})_{m}(\mathrm{MSA})_{n}(m=0-4, n=1-4)$ clusters. The details for the scheme were presented in our previous study. ${ }^{11,63}$ Briefly, around 10000 initial random configurations for each cluster were gradually screened, using various theoretical methods, to find the configuration with the lowest free energy. The employed theoretical methods include PM6, $\omega B 97 X-D / 6-31+G(d, p), \omega B 97 X-D / 6-31++G(d, p)$ and DLPNO-CCSD(T)/aug- 
105

106

114 they have shown good performance for studying the formation of atmospheric

115 molecular cluster. ${ }^{66-70}$ The Gibbs free energy for each global minima was calculated at

$116298.15 \mathrm{~K}$ by combining the single point energies at the DLPNO-CCSD(T)/aug-cc-

$117 \mathrm{pVTZ}$ level and the Gibbs free energy correction terms at the $\omega \mathrm{B} 97 \mathrm{X}-\mathrm{D} / 6-31++\mathrm{G}(\mathrm{d}, \mathrm{p})$

118 level. The cluster formation free energy $(\Delta G)$ was obtained by subtracting the Gibbs

119 free energy of the constituent molecules from that of the cluster at $298.15 \mathrm{~K}$. The

120 formation free energies at other temperatures were calculated by assuming that enthalpy

121 and entropy change remain constant in the considered tropospheric temperature range.

122 To probe the effect of hydration, the (MEA $)_{m}(\mathrm{MSA})_{n}\left(\mathrm{H}_{2} \mathrm{O}\right)_{x}(m=0-2, n=0-2, x=$

123 1-3) clusters were investigated. The global minima of $(\mathrm{MEA})_{1-2}\left(\mathrm{H}_{2} \mathrm{O}\right)_{1-3}$ were taken

124 from our previous study. ${ }^{11}$ The same scheme as for unhydrated (MEA) $)_{m}(\mathrm{MSA})_{n}$ clusters

125 was used to locate the global minima of the (MEA $)_{m}(\mathrm{MSA})_{n}\left(\mathrm{H}_{2} \mathrm{O}\right)_{x}(m=0-2, n=1-2$, 
$126 x=1-3)$ clusters. In addition, to compare the enhancing potential of MEA with MA, the

127 cluster formation free energies for $(\mathrm{MA})_{0-2}(\mathrm{MSA})_{0-2}$ were calculated at the same level

128 of theory as for the (MEA $)_{m}(\mathrm{MSA})_{n}$ clusters. The $(\mathrm{MA})_{1}(\mathrm{MSA})_{1},(\mathrm{MA})_{2}(\mathrm{MSA})_{2}$ and

$129(\mathrm{MA})_{1}(\mathrm{MSA})_{2}$ cluster structures are available in the literature ${ }^{41,71}$ and the structures of

130 the $(\mathrm{MA})_{2}$ and $(\mathrm{MA})_{2}(\mathrm{MSA})_{1}$ clusters were obtained in this work. It deserves

131 mentioning that there are two reported global minima for cluster $(\mathrm{MA})_{1}(\mathrm{MSA})_{1} .^{71,72}$

132 One involves proton transfer between MA and MSA and the other does not. The one

133 without the proton transfer, which was determined to have lower free energy at the

134 theoretical level of this work, was selected.

135 ACDC Simulation. ACDC was employed to investigate the cluster steady-state (i.e.

136 time independent) concentration, the formation pathways and formation rates of MEA-

137 MSA clusters. ${ }^{59}$ In ACDC, the birth-death equation (Eq. (1)) is used to describe the time

$138(t)$ evolution of molecular cluster distributions:

$$
\frac{d c_{i}}{d t}=\frac{1}{2} \sum_{j<i} \beta_{j,(i-j)} c_{j} c_{(i-j)}+\sum_{j} \gamma_{(i+j) \rightarrow i} c_{i+j}-\sum_{j} \beta_{i, j} c_{i} c_{j}-\frac{1}{2} \sum_{j<i} \gamma_{i \rightarrow j} c_{i}+Q_{i}-S_{i}
$$

140 where subscripts $i, j, i-j, j-i$ and $i+j$ represent different clusters (or monomers) in the

141 system, $c$ represents the concentration of a cluster (or monomer), $\beta$ is the collision

142 coefficient between two clusters (or monomers), $\gamma$ represents the evaporation coefficient

143 of a cluster $(i+j)$ which evaporates into its daughter cluster $(i)$ as illustrated by the arrow

144 of the subscript. $Q_{i}$ represents additional outside sources and $S_{i}$ represents the sink terms.

$145 \beta$ and $\gamma$ were calculated by Eq. (2) and Eq. (3) (taking $\beta_{i, j}$ and $\gamma_{(i+j) \rightarrow i}$ as examples), respectively. 


$$
\beta_{i, j}=\left(\frac{3}{4 \pi}\right)^{1 / 6}\left(\frac{6 k_{b} T}{m_{i}}+\frac{6 k_{b} T}{m_{j}}\right)^{1 / 2}\left(V_{i}^{1 / 3}+V_{j}^{1 / 3}\right)^{2}
$$

148 Where $k_{b}$ represents the Boltzmann constant, $T$ represents the temperature, and $m$ and

$149 V$ are the mass and volume of the cluster (or monomer), respectively.

$$
\gamma_{(i+j) \rightarrow i}=\beta_{i, j} c_{\text {ref }} \exp \left\{\frac{\Delta G_{i+j}-\Delta G_{i}-\Delta G_{j}}{k_{b} T}\right\}
$$

151 Where $\Delta G$ represents the formation free energy of a cluster, $c_{\text {ref }}$ is the reference 152 monomer concentration at $1 \mathrm{~atm}$, which is the pressure at which $\Delta G$ was calculated.

153 Here, the ACDC simulation system was treated as a " $4 \times 4$ box" for the unhydrated

154 MEA-MSA cluster system, where 4 is the maximum number of MEA or MSA

155 molecules in the cluster. The $(\mathrm{MEA})_{4}(\mathrm{MSA})_{5}$ and $(\mathrm{MEA})_{5}(\mathrm{MSA})_{5}$ clusters were set as

156 the boundary clusters that are allowed to leave the simulation and contribute to NPF

157 (see detailed description in the Supporting Information (SI)). In the simulation, the

158 MSA concentration [MSA] was set to be $10^{5}, 10^{6}, 10^{7}$ and $10^{8}$ molecules $\mathrm{cm}^{-3}$ and the

159 MEA concentration [MEA] to $1 \mathrm{ppt}\left(\sim 2.50 \times 10^{7}\right.$ molecules $\left.\mathrm{cm}^{-3}\right), 10 \mathrm{ppt}\left(\sim 2.50 \times 10^{8}\right.$

160 molecules $\left.\mathrm{cm}^{-3}\right)$, and $100 \mathrm{ppt}\left(\sim 2.50 \times 10^{9}\right.$ molecules $\left.\mathrm{cm}^{-3}\right)$. The simulations were

161 mainly run at $278.15 \mathrm{~K}$, with additional runs at $258.15,268.15,278.15,288.15$, and

$162298.15 \mathrm{~K}$, to probe the effect of temperature. Since there is no available value of the

163 coagulation sink coefficient for MSA vapor, we chose a constant coagulation sink

164 coefficient of $2.60 \times 10^{-3} \mathrm{~s}^{-1}$ to account for the loss of clusters. This value is based on

165 the median condensation sink of sulfuric acid vapor on pre-existing aerosol particles at

166 Hyytiälä, Finland. ${ }^{73,74}$ In addition, within the range from $6 \times 10^{-4} \mathrm{~s}^{-1}$ to $6 \times 10^{-2} \mathrm{~s}^{-1}$, 
covering possible condensation sink coefficients in clean and haze days, ${ }^{75,76}$ the effect

168 of coagulation sink coefficient on results is examined. 1 was used as the sticking factor

169 in all simulations with additional tests at 0.1 and $0.01 .^{59,73}$ Unless noted, $2.60 \times 10^{-3} \mathrm{~s}^{-1}$

170 for coagulation sink coefficient, 1 for sticking factor and $278.15 \mathrm{~K}$ for temperature are

171 used throughout ACDC simulation. For the hydrated MEA-MSA cluster, the simulation

172 system was treated as a " $2 \times 2$ box" and the clusters $(\mathrm{MEA})_{2}(\mathrm{MSA})_{3}$ and

$173(\mathrm{MEA})_{3}(\mathrm{MSA})_{3}$ clusters were set as the boundary clusters. The simulation was run at

$174278.15 \mathrm{~K}$ with $[\mathrm{MEA}]=10 \mathrm{ppt}\left(\sim 2.50 \times 10^{8}\right.$ molecules $\left.\mathrm{cm}^{-3}\right)$ and $[\mathrm{MSA}]=10^{6}$

175 molecules $\mathrm{cm}^{-3}$.

176 ACDC simulation was also performed using a " $2 \times 2$ box" for the MA-MSA

177 system as a comparison. The $(\mathrm{MA})_{2}(\mathrm{MSA})_{3}$ and $(\mathrm{MA})_{3}(\mathrm{MSA})_{3}$ were set as the

178 boundary clusters and other simulation settings were similar to those of the MEA-MSA

179 system. In addition, we also run ACDC simulations for the MEA-MSA system with a

180 "2 $\times 2$ box" for a direct comparison with the MA-MSA system under the same

181 conditions.

182 RESULTS AND DISCUSSION

183 Cluster Structures. The located lowest free energy conformations of the

$184(\mathrm{MEA})_{m}(\mathrm{MSA})_{n}(m=0-4, n=1-4)$ clusters are presented in Figure 1. All the identified

185 cluster structures and thermochemistry have been added to the Atmospheric Cluster

186 Database. ${ }^{77}$ Here, we only discuss the $(\mathrm{MEA})_{m}(\mathrm{MSA})_{n}(m=0-4, n=1-4)$ clusters, since

187 the pure $(\mathrm{MEA})_{m}(m=1-4)$ clusters have been analyzed in our previous study. ${ }^{11}$ In view 
189 group) and the MEA molecule only has one available site $\left(-\mathrm{NH}_{2}\right.$ group) that can be

190 protonated. Therefore, only "one to one" proton transfer pattern can occur between

191 MEA and MSA. As can be seen in Figure 1, there is no proton transfer in the 192 homomolecular $(\mathrm{MSA})_{n}(n=1-4)$ clusters and the pure (MSA $)_{n}$ clusters are mainly 193 stabilized by hydrogen bonds (H-bonds), similar to the case of (MEA) $m(m=1-4)$

194 clusters. ${ }^{11}$ However, proton transfers occur in all the heteromolecular (MEA) $m(\mathrm{MSA})_{n}$ 195 ( $m=1-4, n=1-4)$ clusters, and the clusters are stabilized by both H-bonds and 196 electrostatic interactions between positive and negative species. When MEA molecules 197 are not less than MSA molecules in the clusters $(m \geq n)$, all the MSA molecules donate 198 their protons to the MEA molecules and $(m-n)$ MEA molecules remains unprotonated.

199 In the case when there is an equal amount of acids and bases in the cluster $(m=n)$, all 200 MEA molecules are protonated. When there are more MSA molecules in the cluster 201 compared to MEA $(m<n), m$ of the MSA molecules donate their protons to $m$ MEA 202 molecules and $(n-m)$ MSA molecules are kept intact. Thus, the number of the proton 203 transfers is equal to the lower value of $m$ or $n$. In the case of all heteromolecular $204(\mathrm{MEA})_{m}(\mathrm{MSA})_{n}(m=1-4, n=1-4)$ clusters where $m=n$, the number of proton transfers 205 is equal to $m$ or $n$. 


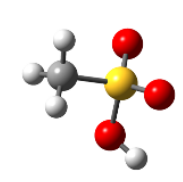

MSA

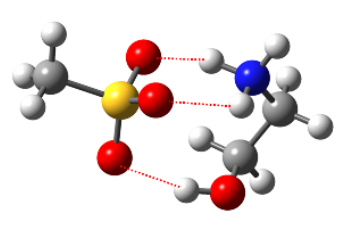

$(\text { MEA })_{1}(\text { MSA })_{1}$

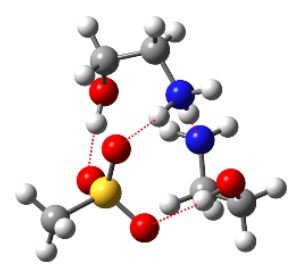

$(\mathrm{MEA})_{2}(\mathrm{MSA})_{1}$

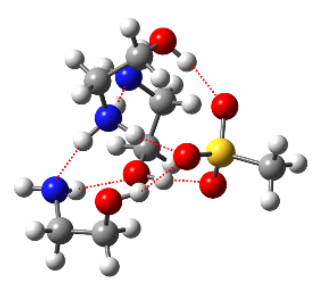

$(\text { MEA })_{3}(\text { MSA })_{1}$

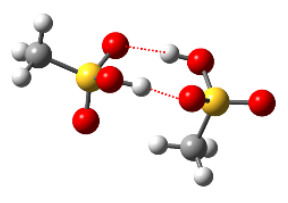

$(\mathrm{MSA})_{2}$

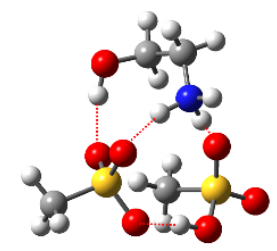

$(\mathrm{MEA})_{1}(\mathrm{MSA})_{2}$

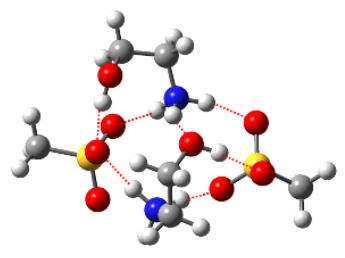

$(\mathrm{MEA})_{2}(\mathrm{MSA})_{2}$

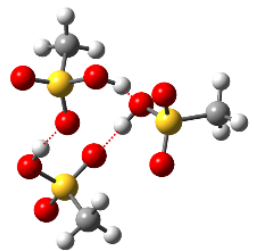

$(\mathrm{MSA})_{3}$

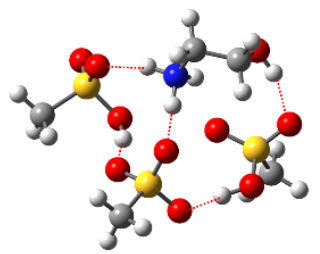

$(\text { MEA })_{1}(\text { MSA })_{3}$

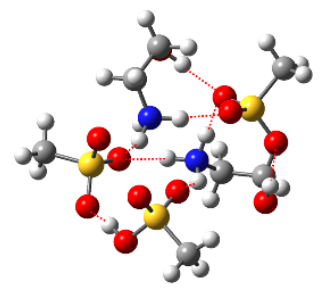

$(\mathrm{MEA})_{2}(\mathrm{MSA})_{3}$

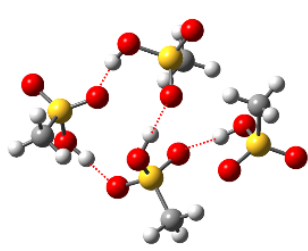

$\left(\right.$ MSA $_{4}$

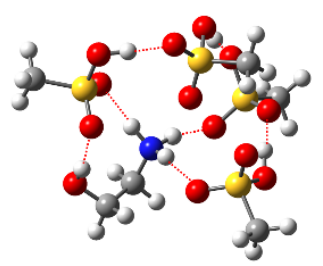

$(\mathrm{MEA})_{1}(\mathrm{MSA})_{4}$

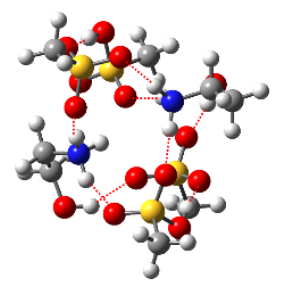

$(\mathrm{MEA})_{2}(\mathrm{MSA})_{4}$
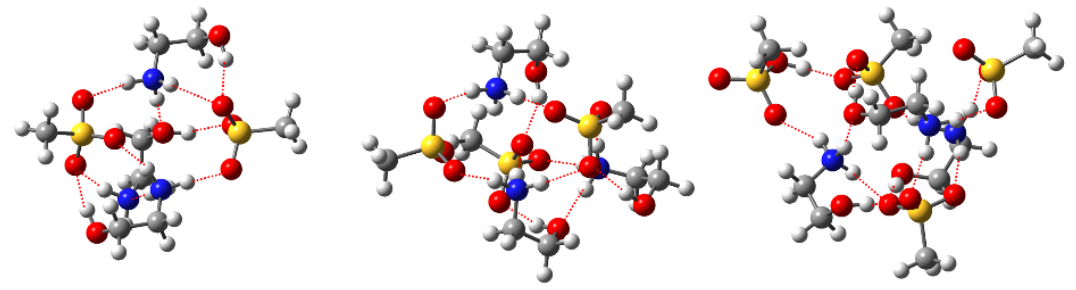

$(\mathrm{MEA})_{3}(\mathrm{MSA})_{2}$

$(\mathrm{MEA})_{3}(\mathrm{MSA})_{3}$

$(\mathrm{MEA})_{3}(\mathrm{MSA})_{4}$
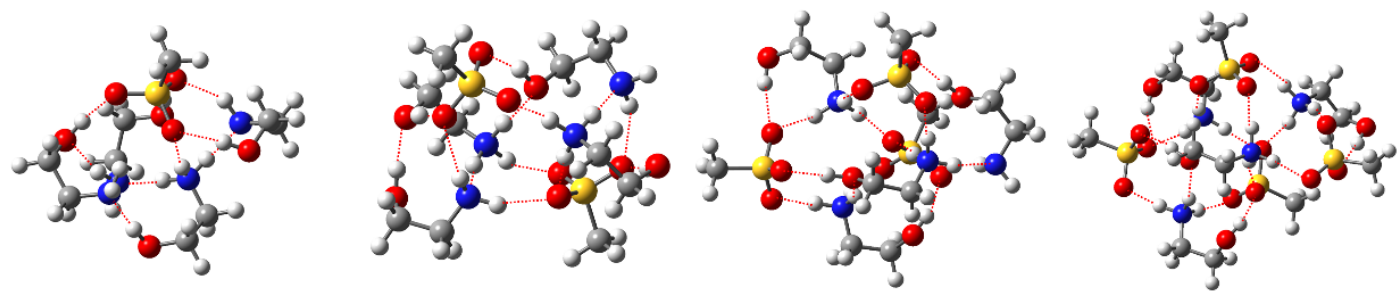

206

$(\mathrm{MEA})_{4}(\mathrm{MSA})_{1}$

$(\mathrm{MEA})_{4}(\mathrm{MSA})_{2}$

$(\mathrm{MEA})_{4}(\mathrm{MSA})_{3}$

$\left(\mathrm{MEA}_{4}\left(\mathrm{MSA}_{4}\right.\right.$

207 Figure 1. Lowest Gibbs free energy conformations of the (MEA) $)_{m}(\mathrm{MSA})_{n}(m=0-4, n$

$208=1-4)$ clusters at the DLPNO-CCSD(T)/aug-cc-pVTZ// $\omega B 97 X-D / 6-31++G(d, p)$ level

209 of theory. The red balls represent oxygen atoms, blue ones for nitrogen atoms, gray

210 ones for carbon atoms, and white ones for hydrogen atoms. Dashed red lines indicate

211 hydrogen bonds. 
$2131-4, n=1-4)$ clusters is that the -OH group in all MEA molecules can form at least one

214 H-bond with MSA as a H-bond donor. In many of the clusters such as (MEA) $)_{2}(\mathrm{MSA})_{2}$,

$215(\mathrm{MEA})_{3}(\mathrm{MSA})_{1},(\mathrm{MEA})_{3}(\mathrm{MSA})_{2},(\mathrm{MEA})_{3}(\mathrm{MSA})_{3},(\mathrm{MEA})_{3}(\mathrm{MSA})_{4},(\mathrm{MEA})_{4}(\mathrm{MSA})_{1}$,

$216(\mathrm{MEA})_{4}(\mathrm{MSA})_{2},(\mathrm{MEA})_{4}(\mathrm{MSA})_{3}$ and $(\mathrm{MEA})_{4}(\mathrm{MSA})_{4}$, the $-\mathrm{OH}$ group of MEA can act

217 as H-bond acceptor and form additional $\mathrm{H}$-bonds with the $-\mathrm{NH}_{2}$ groups of MEAs, -

$218 \mathrm{NH}_{3}{ }^{+}$groups of protonated MEAs, or the -OH group of another MEA. The participation

219 of the -OH group of MEA in forming H-bonds was also found in the MEA-SA clusters

220 in our previous study. ${ }^{11}$ In addition, all protonated and unprotonated $-\mathrm{NH}_{2}$ groups of

221 MEA at least participate in one H-bond formation. Such multiple H-bonds formed by

222 MEA lead to the formation of an internal network in the MEA-containing clusters,

223 which make the cluster prefer to form a spherical three dimensional structure, especially

224 for large MEA-MSA clusters. Actually, the formation of an internal H-bond network

225 forces the hydrophobic $-\mathrm{CH}_{3}$ group of MSA to be kept at the outer edge of the clusters.

226 Cluster Formation Free Energy Surface. MA is known as the strongest enhancing 227 agent in MSA-driven NPF. ${ }^{41,42}$ Here, $\Delta G$ values of the MA-MSA system were used as 228 a comparison point for the MEA-MSA system. The formation free energy surface at $229298.15 \mathrm{~K}$ for MEA-MSA system is presented in Figure 2, along with that for the MA230 MSA system (only the (MA) $0-2(\mathrm{MSA})_{0-2}$ clusters are available). The corresponding 231 thermodynamical quantities $\Delta H$ and $\Delta S$ are presented in Table $\mathrm{S} 1$. As can be seen in 232 Figure 2, the $\Delta G$ value of each MEA-containing cluster is significantly lower than that 
233 of the corresponding MA-containing cluster within the available MA-MSA cluster size.

234 The difference in $\Delta G$ value between the MEA-MSA cluster and the corresponding MA-

235 MSA cluster is in the range 1.81-10.65 $\mathrm{kcal} \mathrm{mol}^{-1}$. Combined with the cluster structure

236 analysis in previous section, we can conclude that such a large difference should result

237 from both a higher gas-phase basicity and higher H-bonding capacity of MEA 238 compared to those of MA.
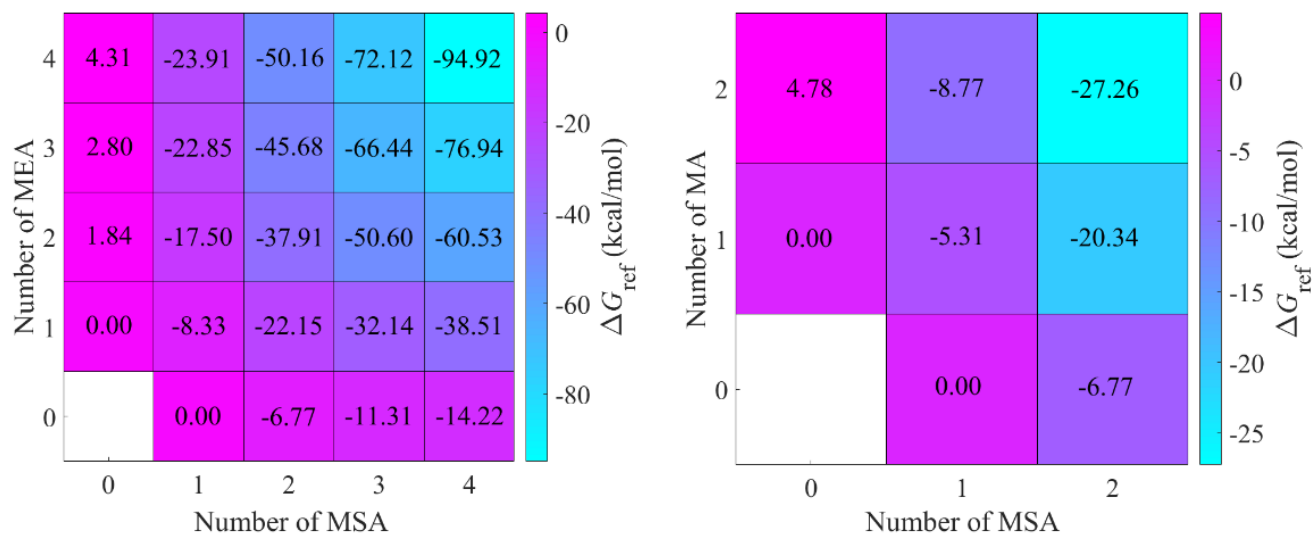

240 Figure 2. Gibbs free binding energy of the (MEA $)_{m}(\mathrm{MSA})_{n}(m=0-4, n=0-4)$ clusters

241 (left panel) and (MA) $)_{a}(\mathrm{MSA})_{b}(a=0-2, b=0-2)$ clusters (right panel) calculated at the

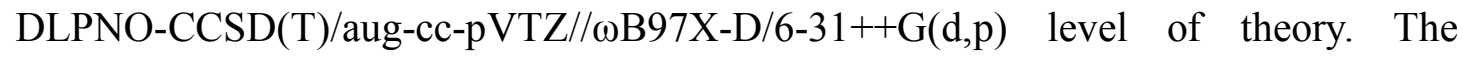

243 calculations are performed at $298.15 \mathrm{~K}$ and $1 \mathrm{~atm}$.

244 Evaporation Rates. The evaporation rates of the clusters in the MEA-MSA system and 245 the MA-MSA system are presented in Figure 3. As can be seen in Figure 3, the 246 evaporation rates for the MEA-MSA clusters $\left((\mathrm{MEA})_{2}(\mathrm{MSA})_{2},(\mathrm{MEA})_{3}(\mathrm{MSA})_{3}\right.$ and $\left.247(\mathrm{MEA})_{4}(\mathrm{MSA})_{4}\right)$ along the diagonal line of the grid are much lower than those of the 248 other clusters, with a range of $10^{-5}-10^{-3} \mathrm{~s}^{-1}$. Clusters with such low evaporation rates can 249 be deemed stable against evaporation at atmospheric conditions when the concentration 
250 of MSA or MEA is at the ppt level (see SI). In addition, the evaporation rates of the

251 clusters above the diagonal line are much higher than those of the corresponding

252 clusters beneath the diagonal line, indicating that MSA abundant clusters are more

253 stable than corresponding MEA abundant clusters. By inspecting all possible

254 evaporation pathways (see SI), it was found that the evaporation of a MEA or MSA

255 monomer is the main decay route for all clusters except (MSA) 4 , for which the

256 evaporation into two MSA dimers is the most favorable path. When $m \geq n$, the

257 (MEA $)_{m}(\mathrm{MSA})_{n}$ clusters decay mainly via evaporation of a MEA monomer. Vice versa

258 is observed for $m<n$, where the evaporation of a MSA monomer is dominant. For the

259 largest studied $(\mathrm{MEA})_{4}(\mathrm{MSA})_{4}$ cluster, the rate for the evaporation route

$260(\mathrm{MEA})_{4}(\mathrm{MSA})_{4} \rightarrow(\mathrm{MEA})_{2}(\mathrm{MSA})_{2}+(\mathrm{MEA})_{2}(\mathrm{MSA})_{2}$ is close to that of the most

261 favorable route $(\mathrm{MEA})_{4}(\mathrm{MSA})_{4} \rightarrow(\mathrm{MEA})_{3}(\mathrm{MSA})_{4}+\mathrm{MEA}$, implying that the

$262(\mathrm{MEA})_{2}(\mathrm{MSA})_{2}$ cluster is relatively stable in the studied system.

263 We also compare the evaporation rates of MEA-MSA clusters with the

264 corresponding MA-MSA clusters up to $2 \times 2$ size of the MA-MSA clusters. As can be

265 seen in Figure 3, the evaporation rate of each of the MA-containing clusters is in all

266 cases higher than that of corresponding MEA-containing cluster. Therefore, we can

267 conclude that MEA can form more stable clusters with MSA than MA at the same acid

268 and base concentration. 

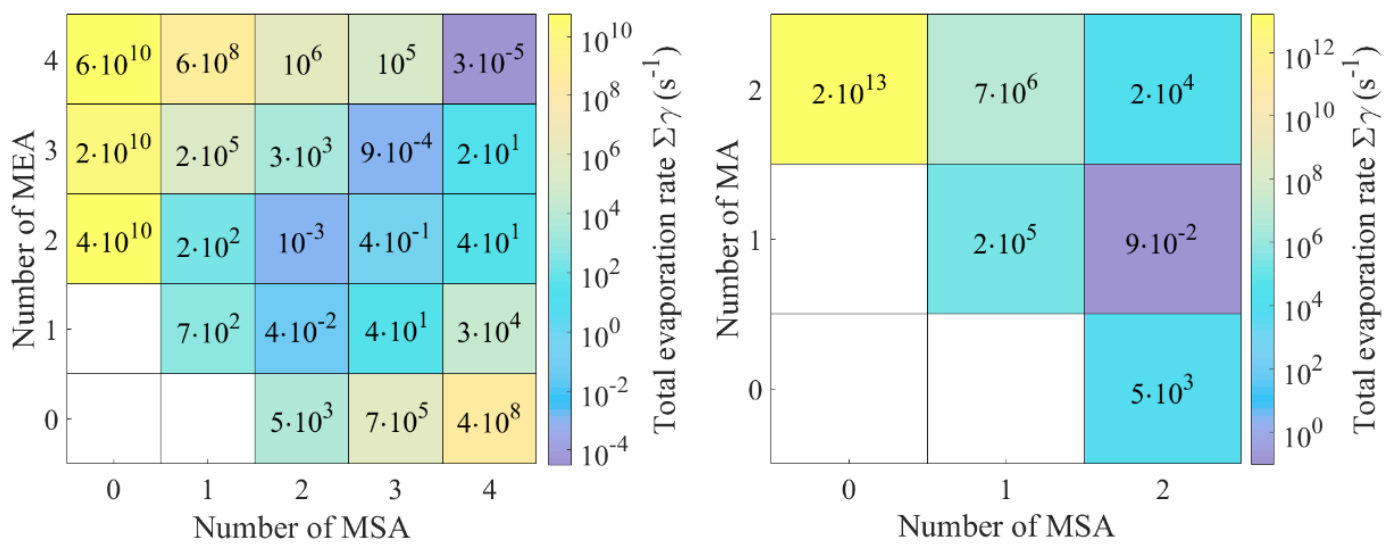

270 Figure 3. Evaporation rates of $(\mathrm{MEA})_{m}(\mathrm{MSA})_{n}(m=0-4$ and $n=0-4)$ (left panel) and

$271(\mathrm{MA})_{a}(\mathrm{MSA})_{b}$ clusters $(a=0-2$ and $b=0-2)($ right panel) at $278.15 \mathrm{~K}$.

272 Clusters Growth Pathways. Figure 4 shows the cluster growth pathways and actual

273 Gibbs free energy surface for the MEA-MSA clusters at $278.15 \mathrm{~K}$, [MSA] $=10^{6}$

274 molecules $\mathrm{cm}^{-3}$, and $[\mathrm{MEA}]=10 \mathrm{ppt}\left(\sim 2.50 \times 10^{8}\right.$ molecules $\left.\mathrm{cm}^{-3}\right)$. As can be seen in

275 Figure 4, the main pathway for MEA-MSA cluster growth is the following: the first

276 step is the binding of one MSA molecule to one MEA molecule to form the $277(\mathrm{MEA})_{1}(\mathrm{MSA})_{1}$ cluster. After the initial step, the growth mainly proceeds by firstly 278 adding one MSA molecule, and then one MEA molecule, similar to the case of the 279 MEA-SA system. ${ }^{11}$ In contrast to the MEA-SA system,,${ }^{11}$ the (MSA) $)_{2}$ acid dimer shows 280 a nonnegligible contribution to the initially formed clusters. This could mainly result 281 from the lower stability of the (MEA) $)_{1}(\mathrm{MSA})_{1}$ cluster compared to that of $(\mathrm{MEA})_{1}(\mathrm{SA})_{1}$. 282 Among the clusters fluxing out of the " $4 \times 4$ box", $(\text { MEA })_{4}(\mathrm{MSA})_{5}$ is the most 283 prominent one with a $99 \%$ contribution. Comparing the growth pathway with the 284 evaporation rate of the clusters, we can conclude that the formation of the initial 285 (MEA $)_{1}(\mathrm{MSA})_{1}$ cluster is the rate-determining step for the cluster growth since the 
286 (MEA $)_{1}(\mathrm{MSA})_{1}$ cluster is the most unstable among all the clusters in the main cluster 287 growth pathway. In addition, as shown in Figure S4 and S5, both coagulation sink 288 coefficient and sticking factor slightly affect the cluster growth pathways.

289 The cluster growth pathway of MEA-MSA clusters was compared with that of the 290 corresponding MA-MSA clusters within the " $2 \times 2$ box" size at the same simulation 291 conditions (see Figure S7). The significant difference in the cluster growth pathway 292 between the two systems lies in the formation of the initial cluster. For the MEA-MSA 293 system, the formed initial cluster is mainly (MEA) $)_{1}(\mathrm{MSA})_{1}$, however, for the MA-MSA 294 system, the dominant initial cluster is the (MSA) 2 cluster. Such difference can be 295 explained by the higher stability of $(\mathrm{MEA})_{1}(\mathrm{MSA})_{1}$ compared to $(\mathrm{MA})_{1}(\mathrm{MSA})_{1}$ at the 296 studied acid and base concentration.
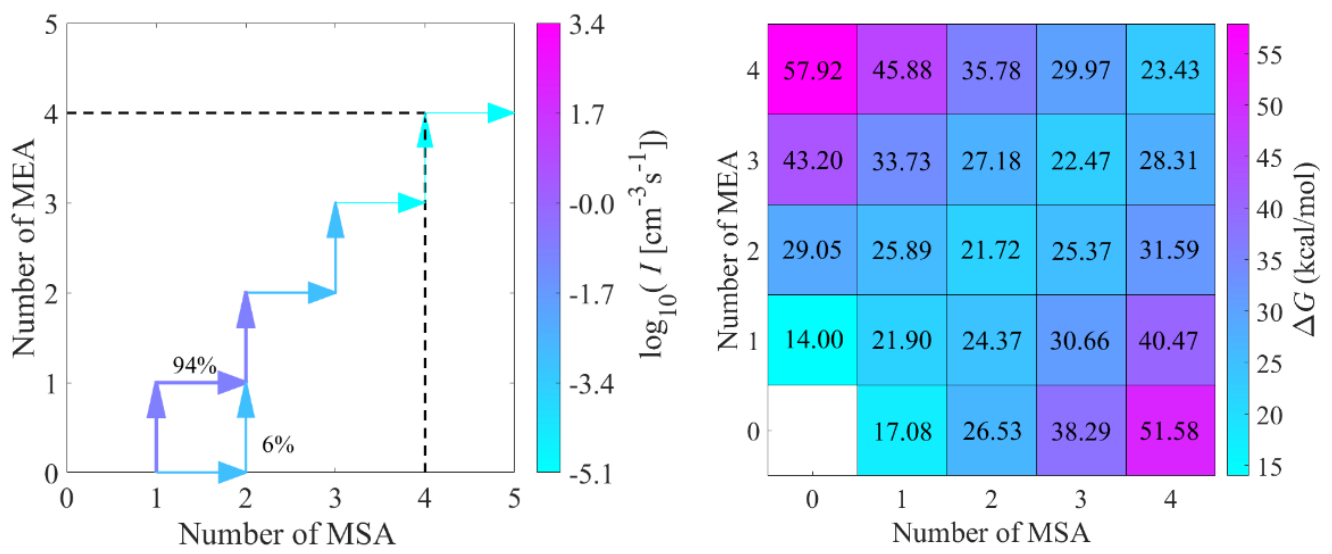

298 Figure 4. Cluster formation pathways (left panel) and actual formation free energy 299 surface (right panel) for the MEA-MSA system at $278.15 \mathrm{~K},[\mathrm{MSA}]=10^{6}$ molecules $\mathrm{cm}^{-3}$, and $[\mathrm{MEA}]=10 \mathrm{ppt}$. For clarity, pathways contributing less than $5 \%$ to the flux 301 of the cluster are not shown. 
steady-state concentration of the acid dimer $\left(\sum(\mathrm{MSA})_{2}\right.$, all clusters including acid

304 dimers) and cluster formation rate can be used to evaluate the enhancing potential of a

305 given base on MSA-driven NPF similar to the case of SA-driven NPF. ${ }^{11,25,78}$ Figure 5

306 presents the steady-state $\sum(\mathrm{MSA})_{2}$ concentration and cluster formation rate as a

307 function of the concentration of MSA $\left(10^{5}-10^{8}\right.$ molecules $\left.\mathrm{cm}^{-3}\right)$ and MEA (1-100 ppt )

308 for the MEA-MSA system at $278.15 \mathrm{~K}$. The MA-MSA cluster system is included as a

309 comparison. Figure 5 shows that with increasing concentration of MSA and MEA, the

$310 \sum(\mathrm{MSA})_{2}$ concentration and cluster formation rate gradually increase at the considered

311 conditions. However, the effect of MEA concentration on the $\sum(\mathrm{MSA})_{2}$ concentration

312 and cluster formation rate gradually become weaker with increasing MEA

313 concentration. This is consistent over the entire considered MSA concentration range,

314 especially in the case of high concentration of MSA. Therefore, the MEA-MSA system

315 approaches saturation with respect to MEA. This behavior is not observed in the MA-

316 MSA system. More importantly, both the $\sum(\mathrm{MSA})_{2}$ concentration and cluster formation

317 rate for the MEA-MSA system are generally much higher than those of a corresponding

318 MA-MSA system in the same concentration of MSA and base. For instance, MEA

319 yields $10-10^{2}$-fold increase in $\sum(\mathrm{MSA})_{2}$ concentration and $10-10^{5}$-fold increase in

320 cluster formation rate compared to MA at the considered conditions. Another way of

321 viewing this is that $0.44-0.63 \mathrm{ppt}$ MEA ([MSA] $=10^{6}$ molecules $\left.\mathrm{cm}^{-3}\right)$ and $0.20-0.29$

322 ppt MEA $\left([\mathrm{MSA}]=10^{7}\right.$ molecules $\left.\mathrm{cm}^{-3}\right)$ can reach a similar enhancing effect as MA 
324 obtained by adjusting the concentration of MEA in ACDC simulations until the 325 calculated cluster formation rate of MEA is similar to that of 5-10 ppt MA). Note that 326 we compare a " $4 \times 4$ box" simulation for the MEA-MSA system to the " $2 \times 2$ box" 327 simulation for the MA-MSA system. If a " $2 \times 2$ box" size is used also for the MEA328 MSA system, the difference in cluster formation rate becomes even more pronounced (see SI). All in all, we can conclude that MEA has a significantly higher enhancing potential than MA on MSA-driven NPF.
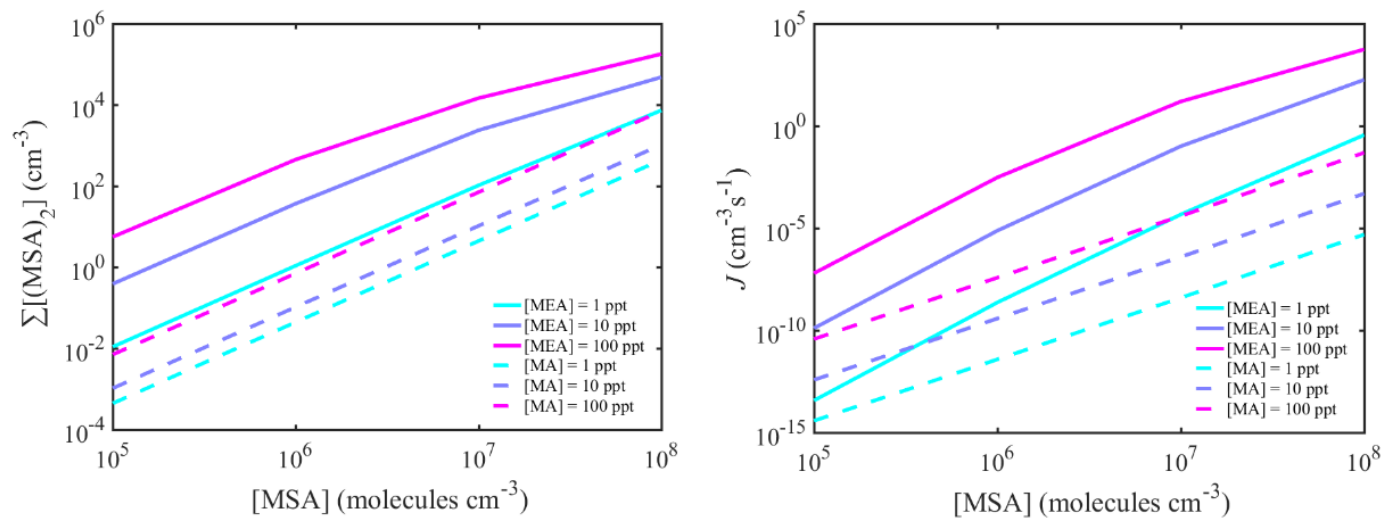

332 Figure 5. Simulated steady-state MSA dimer concentration $\Sigma\left[(\mathrm{MSA})_{2}\right]\left(\mathrm{cm}^{-3}\right)$ and the 333 cluster formation rate $J\left(\mathrm{~cm}^{-3} \mathrm{~s}^{-1}\right)$ as a function of monomer concentration at $278.15 \mathrm{~K}$.

334 Effect of Hydration. Hydration can affect the NPF kinetics and thermodynamics of 335 MSA and bases. ${ }^{79-81}$ Previous studies have shown that SA-base (base $=$ ammonia, DMA 336 and MEA) clusters are mainly hydrated by less than three $\mathrm{H}_{2} \mathrm{O}$ molecules. ${ }^{13}$ Compared 337 with SA, MSA is less hygroscopic and thus should be less hydrated. ${ }^{29}$ Here, one to three $338 \mathrm{H}_{2} \mathrm{O}$ molecules were considered to study the effect of hydration on the formation 339 kinetics of the MEA-MSA clusters. Similar to our previous studies, ${ }^{11,63}$ only the smaller 
$340(\mathrm{MEA})_{m}(\mathrm{MSA})_{n}(m=0-2, n=0-2)$ clusters were considered as a test to investigate the

341 effect of hydration. The optimized configurations of the hydrated clusters and the

342 stepwise hydration free energy are presented in Figure S9 and Table S3, respectively.

343 The equilibrium hydrate distribution at $278.15 \mathrm{~K}$ and relative humidity $(\mathrm{RH})$ of $20 \%$,

$34450 \%$, and $80 \%$ are presented in Figure S10. Figure S10 shows that all heteromolecular

345 clusters except $(\mathrm{MEA})_{1}(\mathrm{MSA})_{1}$ and $(\mathrm{MEA})_{2}(\mathrm{MSA})_{2}$ are predominantly hydrated by 1-

$3462 \mathrm{H}_{2} \mathrm{O}$ molecules, and all homomolecular clusters except MSA are barely hydrated at

347 all the studied RHs. (MEA) $)_{1}(\mathrm{MSA})_{1}$ and $(\mathrm{MEA})_{2}(\mathrm{MSA})_{2}$ can be hydrated by $3 \mathrm{H}_{2} \mathrm{O}$

348 molecules and MSA by $1 \mathrm{H}_{2} \mathrm{O}$ molecule, which implies that clusters with an equal

349 amount of acid and base molecules are more hydrophilic. Therefore, it can be concluded

350 that the MEA-MSA clusters can be mildly hydrated with 1-3 $\mathrm{H}_{2} \mathrm{O}$ molecules depending

351 on RH.

352 The relative evaporation rate and cluster formation rate as a function of $\mathrm{RH}$ at

$353278.15 \mathrm{~K}$ compared to dry conditions are presented in Figure 6. The effect of hydration

354 depends on the cluster composition for the (MEA $)_{m}(\mathrm{MSA})_{n}(m=0-2, n=0-2)$ clusters.

355 The evaporation rates of $(\mathrm{MEA})_{2}$ and $(\mathrm{MEA})_{2}(\mathrm{MSA})_{2}$ are almost unchanged and

$356(\mathrm{MSA})_{2}$ is slightly increased by hydration. However, the evaporation rates of the

$357(\mathrm{MEA})_{1}(\mathrm{MSA})_{2}$ and $(\mathrm{MEA})_{2}(\mathrm{MSA})_{1}$ clusters were found to increase by up to 8 and 14

358 times by the hydration, respectively. More importantly, hydration significantly

359 decreases the evaporation rate (up to 50 times compared to the dry condition) of the

360 initially formed (MEA) $)_{1}(\mathrm{MSA})_{1}$ cluster, which was shown to be the rate-determining 
361 step for the cluster growth in the system. The decreased evaporation rate of the $362(\mathrm{MEA})_{1}(\mathrm{MSA})_{1}$ cluster is the main reason that the cluster formation rate is significant 363 increased (up to 18 times, right panel in Figure 6) and (MEA) $1(\mathrm{MSA})_{1}$ contributes more 364 to the initially formed clusters compared to the anhydration case (Figure S11). Note 365 that the relative formation rate presented here should cancel out any significant bias 366 introduced by the smaller " $2 \times 2$ box" size. Generally, from these small cluster 367 hydration simulations, we can conclude that hydration can significantly affect the 368 cluster formation rates. This is different from the SA-amine (MA, DMA and MEA) 369 cluster systems, in which hydration has a little effect on the cluster formation rates. ${ }^{11}$ 370 We note that the experiments from Finlayson-Pitts group showed that an increase in the 371 RH greatly increased the nucleation rate of MSA-base (base = ammonia, MA, DMA 372 and TMA), ${ }^{41}$ which is similar to our findings.
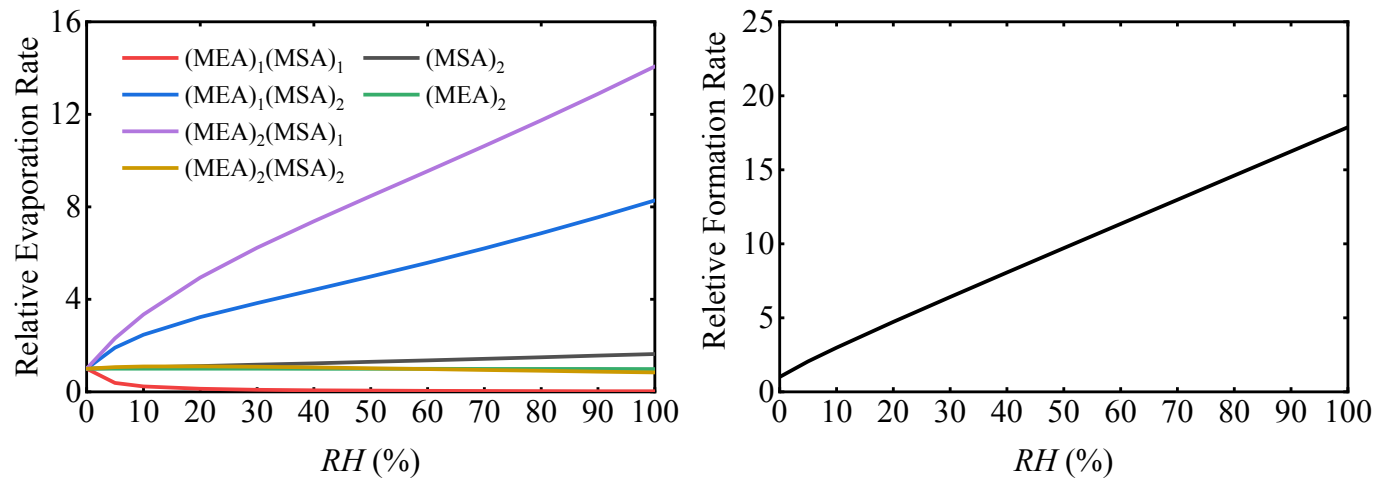

374 Figure 6. Relative evaporation rate (left panel) and cluster formation rate $\left([\mathrm{MSA}]=10^{6}\right.$ 375 molecules $\mathrm{cm}^{-3}$ and $[\mathrm{MEA}]=10 \mathrm{ppt}$ ) (right panel) as a function of relative humidity $376(\mathrm{RH})$ at $278.15 \mathrm{~K}$.

377 Uncertainty Analysis of the ACDC Simulations. Here, the potential uncertainties 378 arising from the manner that ACDC is calculating the collision rate coefficients are 
379 analyzed. We also investigate how variable settings, such as sticking factor and 380 coagulation sink coefficient, affect the main results. Since the cluster formation process 381 does not involve chemical reaction energy barriers, ${ }^{82}$ ACDC employs kinetic gas theory 382 to calculate the collision rate coefficients by assuming that all colliding molecules 383 follow hard-sphere collisions, i.e. there is no specific interaction between the colliding 384 molecules. We noted that recent studies by Lin et al. and Lee et al. argued that the 385 dipole-dipole interaction between colliding molecules could play an important role in 386 enhancing collision rates. ${ }^{83,84}$ To address the possible uncertainty resulting from kinetic 387 gas theory, we employed the long-range transition state theory with a dipole-dipole 388 force potential and the statistical adiabatic channel model, ${ }^{85,86}$ as test methods to 389 calculate the collision rate coefficients between monomers in MEA-MSA and MA390 MSA cluster systems at $278.15 \mathrm{~K}$. Both theories explicitly consider dipole-dipole 391 interactions between the molecules (see computational details in SI). As can be seen in 392 Table S7, there is a maximum of about 2 times difference in the collision rate 393 coefficients between the two test methods and kinetic gas theory. Therefore, the kinetic 394 gas theory employed in ACDC should provide reasonable collision rate coefficients for 395 the MEA-MSA and MA-MSA cluster systems. In addition, both sticking factor and 396 coagulation sink coefficient can affect the enhancing potential (the concentration of $397 \sum(\mathrm{MSA})_{2}$ and cluster formation rates) of MEA and MA on MSA-driven NPF (detailed 398 discussion in SI). However, within all considered change range of coagulation sink 
399

417 the H-bonding capacity of the non-amino group plays an important role in determining

418 the enhancing potential of amines on MSA-based NPF. In the atmosphere, many bases 419 have a high gas-phase basicity and H-bonding capacity from non-amino groups, e.g. 
420 diamines and amino acids. Moreover, highly oxygenated multifunctional molecules

421 (HOMs) with an amino group could also contribute to MSA-based NPF due to their

422 high H-bonding capacity. ${ }^{87,88}$ Therefore, the enhancing potential of diamine, amino acid,

423 and HOMs with an amino group on MSA-driven NPF deserves future investigation to

424 comprehensively understand the contribution of MSA on NPF.

\section{ASSOCIATED CONTENT}

426 Supporting Information. Details for judging of cluster stability and boundary

427 conditions, effect of temperature, effect of variables settings of ACDC, effect of

428 hydration on cluster formation pathways, computational details for collision rate

429 coefficients from test methods, thermodynamics information for the formation of

430 molecular clusters, evaporation coefficients for all evaporation pathways of different

431 clusters, hydration free energies, conformations of MA-MSA clusters and hydrate

432 MEA-MSA clusters, the main clustering pathways for MA-MSA clusters, comparison

433 for steady-state MSA dimer concentration and the cluster formation rate with a " $2 \times 2$

434 box" simulation between MEA-MSA and MA-MSA system, hydration distribution of

435 clusters and coordinates of all optimized clusters.

436 AUTHOR INFORMATION

437 Corresponding Author

438 *Phone/fax: +86-411-84707251; e-mail:hbxie@dlut.edu.cn

$439 \quad$ Notes

440 The authors declare no competing financial interest. 
The study was supported by the National Natural Science Foundation of China

ERC Project 692891-DAMOCLES, the Academy of Finland, and the University of

Helsinki, Faculty of Science ATMATH Project.

\section{REFERENCES}

(1) Yao, L.; Garmash, O.; Bianchi, F.; Zheng, J.; Yan, C.; Kontkanen, J.; Junninen, H.; Mazon, S. B.; Ehn, M.; Paasonen, P.; Sipila, M.; Wang, M. Y.; Wang, X. K.; Xiao, S.; Chen, H. F.; Lu, Y. Q.; Zhang, B. W.; Wang, D. F.; Fu, Q. Y.; Geng, F. H.; Li, L.; Wang, H. L.; Qiao, L. P.; Yang, X.; Chen, J. M.; Kerminen, V. M.; Petaja, T.; Worsnop, D. R.; Kulmala, M.; Wang, L. Atmospheric New Particle Formation from Sulfuric Acid and Amines in A Chinese Megacity. Science 2018, 361 (6399), 278.

(2) Olenius, T.; Halonen, R.; Kurtén, T.; Henschel, H.; Kupiainen-Määttä, O.; Ortega, I. K.; Jen, C. N.; Vehkamäki, H.; Riipinen, I. New particle formation from sulfuric acid and amines: Comparison of monomethylamine, dimethylamine, and trimethylamine. $J$. Geophys. Res.-Atmos. 2017, 122 (13), 7103-7118.

(3) Almeida, J.; Schobesberger, S.; Kurtén, A.; Ortega, I. K.; Kupiainen-Maatta, O.; Praplan, A. P.; Adamov, A.; Amorim, A.; Bianchi, F.; Breitenlechner, M.; David, A.; Dommen, J.; Donahue, N. M.; Downard, A.; Dunne, E.; Duplissy, J.; Ehrhart, S.; Flagan, R. C.; Franchin, A.; Guida, R.; Hakala, J.; Hansel, A.; Heinritzi, M.; Henschel, H.; Jokinen, T.; Junninen, H.; Kajos, M.; Kangasluoma, J.; Keskinen, H.; Kupc, A.; Kurtén, T.; Kvashin, A. N.; Laaksonen, A.; Lehtipalo, K.; Leiminger, M.; Leppa, J.; Loukonen, V.; Makhmutov, V.; Mathot, S.; McGrath, M. J.; Nieminen, T.; Olenius, T.; Onnela, A.; Petaja, T.; Riccobono, F.; Riipinen, I.; Rissanen, M.; Rondo, L.; Ruuskanen, T.; Santos, F. D.; Sarnela, N.; Schallhart, S.; Schnitzhofer, R.; Seinfeld, J. H.; Simon, M.; Sipila, M.; Stozhkov, Y.; Stratmann, F.; Tome, A.; Trostl, J.; Tsagkogeorgas, G.; Vaattovaara, P.; Viisanen, Y.; Virtanen, A.; Vrtala, A.; Wagner, P. E.; Weingartner, E.; Wex, H.; Williamson, C.; Wimmer, D.; Ye, P.; Yli-Juuti, T.; Carslaw, K. S.; Kulmala, M.; Curtius, J.; Baltensperger, U.; Worsnop, D. R.; Vehkamaki, H.; Kirkby, J. Molecular 
Understanding of Sulphuric Acid-amine Particle Nucleation in the Atmosphere. Nature 2013, 502 (7471), 359-363.

(4) Kirkby, J.; Curtius, J.; Almeida, J.; Dunne, E.; Duplissy, J.; Ehrhart, S.; Franchin, A.; Gagne, S.; Ickes, L.; Kurten, A.; Kupc, A.; Metzger, A.; Riccobono, F.; Rondo, L.; Schobesberger, S.; Tsagkogeorgas, G.; Wimmer, D.; Amorim, A.; Bianchi, F.; Breitenlechner, M.; David, A.; Dommen, J.; Downard, A.; Ehn, M.; Flagan, R. C.; Haider, S.; Hansel, A.; Hauser, D.; Jud, W.; Junninen, H.; Kreissl, F.; Kvashin, A.; Laaksonen, A.; Lehtipalo, K.; Lima, J.; Lovejoy, E. R.; Makhmutov, V.; Mathot, S.; Mikkila, J.; Minginette, P.; Mogo, S.; Nieminen, T.; Onnela, A.; Pereira, P.; Petaja, T.; Schnitzhofer, R.; Seinfeld, J. H.; Sipila, M.; Stozhkov, Y.; Stratmann, F.; Tome, A.; Vanhanen, J.; Viisanen, Y.; Vrtala, A.; Wagner, P. E.; Walther, H.; Weingartner, E.; Wex, H.; Winkler, P. M.; Carslaw, K. S.; Worsnop, D. R.; Baltensperger, U.; Kulmala, M. Role of Sulphuric Acid, Ammonia and Galactic Cosmic Rays in Atmospheric Aerosol Nucleation. Nature 2011, 476 (7361), 429-33.

(5) Zhang, R. Y.; Suh, I.; Zhao, J.; Zhang, D.; Fortner, E. C.; Tie, X. X.; Molina, L. T.; Molina, M. J. Atmospheric New Particle Formation Enhanced by Organic Acids. Science 2004, 304 (5676), 1487-1490.

(6) Winkler, P. M.; Steiner, G.; Vrtala, A.; Vehkamaki, H.; Noppel, M.; Lehtinen, K. E. J.; Reischl, G. P.; Wagner, P. E.; Kulmala, M. Heterogeneous Nucleation Experiments Bridging the Scale from Molecular Ion Clusters to Nanoparticles. Science 2008, 319 (5868), 1374-1377.

(7) Ehn, M.; Thornton, J. A.; Kleist, E.; Sipila, M.; Junninen, H.; Pullinen, I.; Springer, M.; Rubach, F.; Tillmann, R.; Lee, B.; Lopez-Hilfiker, F.; Andres, S.; Acir, I.-H.; Rissanen, M.; Jokinen, T.; Schobesberger, S.; Kangasluoma, J.; Kontkanen, J.; Nieminen, T.; Kurtén, T.; Nielsen, L. B.; Jorgensen, S.; Kjaergaard, H. G.; Canagaratna, M.; Dal Maso, M.; Berndt, T.; Petaja, T.; Wahner, A.; Kerminen, V.-M.; Kulmala, M.; Worsnop, D. R.; Wildt, J.; Mentel, T. F. A Large Source of Low-volatility Secondary Organic Aerosol. Nature 2014, 506 (7489), 476-479.

(8) Wang, Y. H.; Liu, Z. R.; Zhang, J. K.; Hu, B.; Ji, D. S.; Yu, Y. C.; Wang, Y. S. Aerosol Physicochemical Properties and Implications for Visibility During an Intense Haze Episode During Winter in Beijing. Atmos. Chem. Phys. 2015, 15 (6), 3205-3215. (9) Rose, C.; Zha, Q.; Dada, L.; Yan, C.; Lehtipalo, K.; Junninen, H.; Mazon, S. B.; Jokinen, T.; Sarnela, N.; Sipila, M.; Petaja, T.; Kerminen, V. M.; Bianchi, F.; Kulmala, M. Observations of Biogenic Ion-induced Cluster Formation in the Atmosphere. Sci. $A d v .2018,4$ (4), No. eaar5218.

(10) Xu, J.; Perraud, V.; Finlayson-Pitts, B. J.; Gerber, R. B. Uptake of Water by an Acid-base Nanoparticle: Theoretical and Experimental Studies of the Methanesulfonic Acid-methylamine System. Phys. Chem. Chem. Phys. 2018, 20 (34), 22249-22259.

(11) Xie, H. B.; Elm, J.; Halonen, R.; Myllys, N.; Kurtén, T.; Kulmala, M.; Vehkamaki, H. Atmospheric Fate of Monoethanolamine: Enhancing New Particle Formation of Sulfuric Acid as an Important Removal Process. Environ. Sci. Technol. 2017, 51 (15), 8422-8431. 
(12) Kurtén, T.; Loukonen, V.; Vehkamaki, H.; Kulmala, M. Amines Are Likely to Enhance Neutral and Ion-induced Sulfuric Acid-water Nucleation in the Atmosphere More Effectively than Ammonia. Atmos. Chem. Phys. 2008, 8 (14), 4095-4103.

(13) Loukonen, V.; Kurtén, T.; Ortega, I. K.; Vehkamäki, H.; Pádua, A. A. H.; Sellegri, K.; Kulmala, M. Enhancing Effect of Dimethylamine in Sulfuric Acid Nucleation in the Presence of Water - A Computational Study. Atmos. Chem. Phys. 2010, 10 (10), 4961-4974.

(14) Murphy, S. M.; Sorooshian, A.; Kroll, J. H.; Ng, N. L.; Chhabra, P.; Tong, C.; Surratt, J. D.; Knipping, E.; Flagan, R. C.; Seinfeld, J. H. Secondary Aerosol Formation from Atmospheric Reactions of Aliphatic Amines. Atmos. Chem. Phys. 2007, 7 (9), 2313-2337.

(15) Smith, J. N.; Barsanti, K. C.; Friedli, H. R.; Ehn, M.; Kulmala, M.; Collins, D. R.; Scheckman, J. H.; Williams, B. J.; McMurry, P. H. Observations of Aminium Salts in Atmospheric Nanoparticles and Possible Climatic Implications. Proc. Natl. Acad. Sci. U. S. A. 2010, 107 (15), 6634-6639.

(16) Zhao, J.; Smith, J. N.; Eisele, F. L.; Chen, M.; Kuang, C.; McMurry, P. H. Observation of Neutral Sulfuric Acid-amine Containing Clusters in Laboratory and Ambient Measurements. Atmos. Chem. Phys. 2011, 11 (21), 10823-10836.

(17) Erupe, M. E.; Viggiano, A. A.; Lee, S. H. The Effect of Trimethylamine on Atmospheric Nucleation Involving $\mathrm{H}_{2} \mathrm{SO}_{4}$. Atmos. Chem. Phys. 2011, 11 (10), $4767-$ 4775.

(18) Lehtipalo, K.; Rondo, L.; Kontkanen, J.; Schobesberger, S.; Jokinen, T.; Sarnela, N.; Kuerten, A.; Ehrhart, S.; Franchin, A.; Nieminen, T.; Riccobono, F.; Sipila, M.; YliJuuti, T.; Duplissy, J.; Adamov, A.; Ahlm, L.; Almeida, J.; Amorim, A.; Bianchi, F.; Breitenlechner, M.; Dommen, J.; Downard, A. J.; Dunne, E. M.; Flagan, R. C.; Guida, R.; Hakala, J.; Hansel, A.; Jud, W.; Kangasluoma, J.; Kerminen, V.-M.; Keskinen, H.; Kim, J.; Kirkby, J.; Kupc, A.; Kupiainen-Maatta, O.; Laaksonen, A.; Lawler, M. J.; Leiminger, M.; Mathot, S.; Olenius, T.; Ortega, I. K.; Onnela, A.; Petaja, T.; Praplan, A.; Rissanen, M. P.; Ruuskanen, T.; Santos, F. D.; Schallhart, S.; Schnitzhofer, R.; Simon, M.; Smith, J. N.; Trostl, J.; Tsagkogeorgas, G.; Tome, A.; Vaattovaara, P.; Vehkamaki, H.; Vrtala, A. E.; Wagner, P. E.; Williamson, C.; Wimmer, D.; Winkler, P. M.; Virtanen, A.; Donahue, N. M.; Carslaw, K. S.; Baltensperger, U.; Riipinen, I.; Curtius, J.; Worsnop, D. R.; Kulmala, M. The Effect of Acid-base Clustering and Ions on the Growth of Atmospheric Nano-particles. Nat. Commun. 2016, 7, 11594.

(19) Chen, M.; Titcombe, M.; Jiang, J.; Jen, C.; Kuang, C.; Fischer, M. L.; Eisele, F. L.; Siepmann, J. I.; Hanson, D. R.; Zhao, J.; McMurry, P. H. Acid-base Chemical Reaction Model for Nucleation Rates in the Polluted Atmospheric Boundary Layer. Proc. Natl. Acad. Sci. U. S. A. 2012, 109 (46), 18713-18718.

(20) Lv, S.-S.; Miao, S.-K.; Ma, Y.; Zhang, M.-M.; Wen, Y.; Wang, C.-Y.; Zhu, Y.-P.; Huang, W. Properties and Atmospheric Implication of Methylamine-Sulfuric AcidWater Clusters. J. Phy. Chem. A 2015, 119 (32), 8657-8666. 
(21) Sipila, M.; Berndt, T.; Petaja, T.; Brus, D.; Vanhanen, J.; Stratmann, F.; Patokoski, J.; Mauldin, R. L.; Hyvarinen, A. P.; Lihavainen, H.; Kulmala, M. The Role of Sulfuric Acid in Atmospheric Nucleation. Science 2010, 327 (5970), 1243-1246.

(22) Nadykto, A. B.; Yu, F.; Jakovleva, M. V.; Herb, J.; Xu, Y. Amines in the Earth's Atmosphere: A Density Functional Theory Study of the Thermochemistry of PreNucleation Clusters. Entropy 2011, 13 (2), 554-569.

(23) Nadykto, A.; Herb, J.; Yu, F.; Xu, Y.; Nazarenko, E. Estimating the Lower Limit of the Impact of Amines on Nucleation in the Earth's Atmosphere. Entropy 2015, 17 (5), 2764-2780.

(24) Nadykto, A. B.; Herb, J.; Yu, F.; Xu, Y. Enhancement in the Production of Nucleating Clusters due to Dimethylamine and Large Uncertainties in the Thermochemistry of Amine-enhanced Nucleation. Chem. Phys. Lett. 2014, 609, 42-49. (25) Jen, C. N.; McMurry, P. H.; Hanson, D. R. Stabilization of Sulfuric Acid Dimers by Ammonia, Methylamine, Dimethylamine, and Trimethylamine. J. Geophys. Res.: Atmos. 2014, 119 (12), 7502-7514.

(26) Qiu, C.; Zhang, R. Y. Multiphase Chemistry of Atmospheric Amines. Phys. Chem. Chem. Phys. 2013, 15 (16), 5738-5752.

(27) Zhang, R.; Wang, L.; Khalizov, A. F.; Zhao, J.; Zheng, J.; McGraw, R. L.; Molina, L. T. Formation of Nanoparticles of Blue Haze Enhanced by Anthropogenic Pollution. Proc. Natl. Acad. Sci. U. S. A. 2009, 106 (42), 17650-17654.

(28) Xu, W.; Zhang, R. Y. A Theoretical Study of Hydrated Molecular Clusters of Amines and Dicarboxylic Acids. J. Chem. Phys. 2013, 139 (6), 11.

(29) Dawson, M. L.; Varner, M. E.; Perraud, V.; Ezell, M. J.; Gerber, R. B.; FinlaysonPitts, B. J. Simplified Mechanism for New Particle Formation from Methanesulfonic Acid, Amines, and Water via Experiments and ab initio Calculations. Proc. Natl. Acad. Sci. U. S. A. 2012, 109 (46), 18719-18724.

(30) Wehner, B.; Petäjä, T.; Boy, M.; Engler, C.; Birmili, W.; Tuch, T.; Wiedensohler, A.; Kulmala, M. The Contribution of Sulfuric Acid and Non-volatile Compounds on the Growth of Freshly Formed Atmospheric Aerosols. Geophys. Res. Lett. 2005, 32 (17), L17810.

(31) Kirkby, J.; Duplissy, J.; Sengupta, K.; Frege, C.; Gordon, H.; Williamson, C.; Heinritzi, M.; Simon, M.; Yan, C.; Almeida, J.; Trostl, J.; Nieminen, T.; Ortega, I. K.; Wagner, R.; Adamov, A.; Amorim, A.; Bernhammer, A. K.; Bianchi, F.; Breitenlechner, M.; Brilke, S.; Chen, X. M.; Craven, J.; Dias, A.; Ehrhart, S.; Flagan, R. C.; Franchin, A.; Fuchs, C.; Guida, R.; Hakala, J.; Hoyle, C. R.; Jokinen, T.; Junninen, H.; Kangasluoma, J.; Kim, J.; Krapf, M.; Kurten, A.; Laaksonen, A.; Lehtipalo, K.; Makhmutov, V.; Mathot, S.; Molteni, U.; Onnela, A.; Perakyla, O.; Piel, F.; Petaja, T.; Praplan, A. P.; Pringle, K.; Rap, A.; Richards, N. A. D.; Riipinen, I.; Rissanen, M. P.; Rondo, L.; Sarnela, N.; Schobesberger, S.; Scott, C. E.; Seinfeld, J. H.; Sipila, M.; Steiner, G.; Stozhkov, Y.; Stratmann, F.; Tome, A.; Virtanen, A.; Vogel, A. L.; Wagner, A. C.; Wagner, P. E.; Weingartner, E.; Wimmer, D.; Winkler, P. M.; Ye, P. L.; Zhang, X.; Hansel, A.; Dommen, J.; Donahue, N. M.; Worsnop, D. R.; Baltensperger, U.; 
Kulmala, M.; Carslaw, K. S.; Curtius, J. Ion-induced Nucleation of Pure Biogenic Particles. Nature 2016, 533 (7604), 521-526.

(32) Bianchi, F.; Trostl, J.; Junninen, H.; Frege, C.; Henne, S.; Hoyle, C. R.; Molteni, U.; Herrmann, E.; Adamov, A.; Bukowiecki, N.; Chen, X.; Duplissy, J.; Gysel, M.; Hutterli, M.; Kangasluoma, J.; Kontkanen, J.; Kurten, A.; Manninen, H. E.; Munch, S.; Perakyla, O.; Petaja, T.; Rondo, L.; Williamson, C.; Weingartner, E.; Curtius, J.; Worsnop, D. R.; Kulmala, M.; Dommen, J.; Baltensperger, U. New Particle Formation in the Free Troposphere: A Question of Chemistry and Timing. Science 2016, 352 (6289), 1109-1112.

(33) Perraud, V. H., J. R.; Martinez, A. S.; Kalinowski, J.; Meinardi, S.; Dawson, M. L.; Wingen, L.; M.; Dabdub, D. B., D. R.; Gerber, R. B.; Finlayson-Pitts, B. J. The Future of Airborne Sulfur-containing Particles in the Absence of Fossil Fuel Sulfur Dioxide Emissions. Proc. Natl. Acad. Sci. U. S. A. 2015, 112 (44), 13514-13519.

(34) Hodshire, A. L.; Campuzano-Jost, P.; Kodros, J. K.; Croft, B.; Nault, B. A.; Schroder, J. C.; Jimenez, J. L.; Pierce, J. R. The Potential Role of Methanesulfonic Acid (MSA) in Aerosol Formation and Growth and the Associated Radiative Forcings. Atmos. Chem. Phys. 2019, 19 (5), 3137-3160.

(35) Hopkins, R. J. D., Y.; Tivanski, A. V.; Zaveri, R. A.; Berkowitz, C. M.; Tyliszczak, T.; Gilles, M. K.; Laskin, A. Chemical Speciation of Sulfur in Marine Cloud Droplets and Particles: Analysis of Individual Particles from the Marine Boundary Layer over the California Current. J. Geophys. Res.-Atmos. 2008, 113 (D04), 209(1-15).

(36) Arquero, K. D. X., J.; Gerber, R. B.; Finlayson-Pitts, B. J. Particle Formation and Growth from Oxalic Acid, Methanesulfonic Acid, Trimethylamine and Water: a Combined Experimental and Theoretical Study. Phys. Chem. Chem. Phys. 2017, 19 (41), 28286-28301.

(37) Stern, D. I. Global Sulfur Emissions from 1850 to 2000. Chemosphere 2005, 58 (2), 163-175.

(38) Barnes, I.; Hjorth, J.; Mihalopoulos, N. Dimethyl Sulfide and Dimethyl Sulfoxide and Their Oxidation in the Atmosphere. Chem. Rev. 2006, 106 (3), 940-975.

(39) Eisele, F. L. T., D. J. Measurement of the Gas Phase Concentration of $\mathrm{H}_{2} \mathrm{SO}_{4}$ and Methane Sulfonic Acid and Estimates of $\mathrm{H}_{2} \mathrm{SO}_{4}$ Production and Loss in the Atmosphere. J. Geophys. Res.-Atmos. 1993, 98 (D5), 9001-9010.

(40) Berresheim, H. E., T.; Tremmel, H. G.; Allen, A. G.; Hansson, H. C.; Rosman, K.; Dal Maso, M.; Mäkelä, J. M.; Kulmala, M.; O'Dowd, C. D. Gas-aerosol Relationships of $\mathrm{H}_{2} \mathrm{SO}_{4}, \mathrm{MSA}$, and $\mathrm{OH}$ : Observations in the Coastal Marine Boundary Layer at Mace Head, Ireland. J. Geophys. Res.-Atmos. 2002, 107 (D19), PAR 5-1-PAR 5-12.

(41) Chen, H.; Varner, M. E.; Gerber, R. B.; Finlayson-Pitts, B. J. Reactions of Methanesulfonic Acid with Amines and Ammonia as a Source of New Particles in Air. J. Phy. Chem. B 2016, 120 (8), 1526-1536.

(42) Chen, H.; Finlayson-Pitts, B. J. New Particle Formation from Methanesulfonic Acid and Amines/Ammonia as a Function of Temperature. Environ. Sci. Technol. 2017, $51(1), 243-252$. 
640

641

642

643

644

645

646

647

648

649

650

651

652

653

654

655

656

657

658

659

660

661

662

663

664

665

666

667

668

669

670

671

672

673

674

675

676

677

678

679

680

(43) Hunter, E. P. L.; Lias, S. G. Evaluated Gas Phase Basicities and Proton Affinities of Molecules: An Update. J. Phys. Chem. Ref. Data 1998, 27 (3), 413-656.

(44) Yang, Y.; Waller, S. E.; Kreinbihl, J. J.; Johnson, C. J. Direct Link between Structure and Hydration in Ammonium and Aminium Bisulfate Clusters Implicated in Atmospheric New Particle Formation. J. Phys. Chem. Lett. 2018, 9 (18), 5647-5652.

(45) Waller, S. E.; Yang, Y.; Castracane, E.; Racow, E. E.; Kreinbihl, J. J.; Nickson, K. A.; Johnson, C. J. The Interplay Between Hydrogen Bonding and Coulombic Forces in Determining the Structure of Sulfuric Acid-Amine Clusters. J. Phys. Chem. Lett. 2018, 9 (6), 1216-1222.

(46) Xie, H.-B.; He, N.; Song, Z.; Chen, J.; Li, X. Theoretical Investigation on the Different Reaction Mechanisms of Aqueous 2-Amino-2-methyl-1-propanol and Monoethanolamine with $\mathrm{CO}_{2}$. Ind. Eng. Chem. Res. 2014, 53 (8), 3363-3372.

(47) Puxty, G.; Rowland, R.; Allport, A.; Yang, Q.; Bown, M.; Burns, R.; Maeder, M.; Attalla, M. Carbon Dioxide Postcombustion Capture: A Novel Screening Study of the Carbon Dioxide Absorption Performance of 76 Amines. Environ. Sci. Technol. 2009, 43 (16), 6427-6433.

(48) Veawab, A.; Tontiwachwuthikul, P.; Chakma, A. Corrosion Behavior of Carbon Steel in the $\mathrm{CO}_{2}$ Absorption Process Using Aqueous Amine Solutions. Ind. Eng. Chem. Res. 1999, 38 (10), 3917-3924.

(49) Liu, Y. D.; Zhang, L. Z.; Watanasiri, S. Representing Vapor-liquid Equilibrium for an Aqueous MEA- $\mathrm{CO}_{2}$ system Using the Electrolyte Nonrandom-two-liquid Model. Ind. Eng. Chem. Res. 1999, 38 (5), 2080-2090.

(50) Xie, H. B.; Zhou, Y.; Zhang, Y.; Johnson, J. K. Reaction Mechanism of Monoethanolamine with $\mathrm{CO}_{2}$ in Aqueous Solution from Molecular Modeling. J. Phy. Chem. A 2010, 114 (43), 11844-11852.

(51) da Silva, E. F.; Booth, A. M. Emissions from Postcombustion $\mathrm{CO}_{2}$ Capture Plants. Environ. Sci. Technol. 2013, 47 (2), 659-660.

(52) McDonald, B. C.; de Gouw, J. A.; Gilman, J. B.; Jathar, S. H.; Akherati, A.; Cappa, C. D.; Jimenez, J. L.; Lee-Taylor, J.; Hayes, P. L.; McKeen, S. A.; Cui, Y. Y.; Kim, S. W.; Gentner, D. R.; Isaacman-VanWertz, G.; Goldstein, A. H.; Harley, R. A.; Frost, G. J.; Roberts, J. M.; Ryerson, T. B.; Trainer, M. Volatile Chemical Products Emerging as Largest Petrochemical Source of Urban Organic Emissions. Science 2018, 359 (6377), 760-764.

(53) Karl, M.; Wright, R. F.; Berglen, T. F.; Denby, B. Worst Case Scenario Study to Assess the Environmental Impact of Amine Emissions from a $\mathrm{CO}_{2}$ Capture Plant. Int. J. Greenh. Gas Con. 2011, 5 (3), 439-447.

(54) Veltman, K.; Singh, B.; Hertwich, E. G. Human and Environmental Impact Assessment of Postcombustion $\mathrm{CO}_{2}$ Capture Focusing on Emissions from AmineBased Scrubbing Solvents to Air. Environ. Sci. Technol. 2010, 44 (4), 1496-1502.

(55) Kapteina, S. S., K.; Verevkin, S. P.; Heintz, A. Vapor Pressures and Vaporization Enthalpies of a Series of Ethanolamines. J. Chem. Eng. Data 2005, 50 (2), 398-402. 
(56) Huang, X. F.; Deng, C. R.; Zhuang, G. S.; Lin, J.; Xiao, M. X. Quantitative Analysis of Aliphatic Amines in Urban Aerosols Based on Online Derivatization and High Performance Liquid Chromatography. Environ. Sci.: Process Impacts 2016, 18 (7), 796-801.

(57) Borduas, N.; Abbatt, J. P. D.; Murphy, J. G. Gas Phase Oxidation of Monoethanolamine (MEA) with OH Radical and Ozone: Kinetics, Products, and Particles. Environ. Sci. Technol. 2013, 47 (12), 6377-6383.

(58) Zhang, Q.; Anastasio, C. Free and Combined Amino Compounds in Atmospheric Fine Particles (PM2.5) and Fog Waters from Northern California. Atmos. Environ. 2003, 37 (16), 2247-2258.

(59) McGrath, M. J. O., T.; Ortega, I. K.; Loukonen, V.; Paasonen, P.; Kurtén, T.; Kulmala, M.; Vehkamäki, H. Atmospheric Cluster Dynamics Code: a flexible method for solution of the birthdeath equations. Atmos. Chem. Phys. 2012, 12 (5), 2345-2355. (60) Elm, J.; Jen, C. N.; Kurtén, T.; Vehkamaki, H. Strong Hydrogen Bonded Molecular Interactions between Atmospheric Diamines and Sulfuric Acid. J. Phy. Chem. A 2016, $120(20), 3693-3700$.

(61) Elm, J.; Fard, M.; Bilde, M.; Mikkelsen, K. V. Interaction of Glycine with Common Atmospheric Nucleation Precursors. J. Phy. Chem. A 2013, 117 (48), 12990-12997.

(62) Elm, J.; Myllys, N.; Hyttinen, N.; Kurtén, T. Computational Study of the Clustering of a Cyclohexene Autoxidation Product $\mathrm{C}_{6} \mathrm{H}_{8} \mathrm{O}_{7}$ with Itself and Sulfuric Acid. J. Phy. Chem. A 2015, 119 (30), 8414-8421.

(63) Ma, F. F.; Xie, H. B.; Elm, J.; Shen, J. W.; Chen, J. W.; Vehkamaki, H. Piperazine Enhancing Sulfuric Acid-Based New Particle Formation: Implications for the Atmospheric Fate of Piperazine. Environ. Sci. Technol. 2019, 53 (15), 8785-8795. (64) Ffrisch, M. J. T., G. W.; Schlegel, H. B.; Scuseria, G. E.; Robb, M. A.; Cheeseman, J. R.; Scalmani, G.; Barone, V.; Mennucci, B.; Petersson, G. A.; Nakatsuji, H.; Caricato, M.; Li, X.; Hratchian, H. P.; Izmaylov, A. F.; Bloino, J.; Zheng, G.; Sonnenberg, J. L.; Hada, M.; Ehara, M.; Toyota, K.; Fukuda, R.; Hasegawa, J.; Ishida, M.; Nakajima, T.; Honda, Y.; Kitao, O.; Nakai, H.; Vreven, T.; Montgomery, J. A., Jr.; Peralta, J. E.; Ogliaro, F.; Bearpark, M.; Heyd, J. J.; Brothers, E.; Kudin, K. N.; Staroverov, V. N.; Kobayashi, R.; Normand, J.; Raghavachari, K.; Rendell, A.; Burant, J. C.; Iyengar, S. S.; Tomasi, J.; Cossi, M.; Rega, N.; Millam, J. M.; Klene, M.; Knox, J. E.; Cross, J. B.; Bakken, V.; Adamo, C.; Jaramillo, J.; Gomperts, R.; Stratmann, R. E.; Yazyev, O.; Austin, A. J.; Cammi, R.; Pomelli, C.; Ochterski, J. W.; Martin, R. L.; Morokuma, K.; Zakrzewski, V. G.; Voth, G. A.; Salvador, P.; Dannenberg, J. J.; Dapprich, S.; Daniels, A. D.; Farkas, O.; Foresman, J. B.; Ortiz, J. V.; Cioslowski, J.; Fox, D. J. Gaussian 09;. Gaussian, Inc.: Wallingford, CT, 2009.

(65) Neese, F. The ORCA program system. Wiley Interdiscip. Rev. Comput. Mol. Sci. 2012, 2 (1), 73-78.

(66) Elm, J.; Bilde, M.; Mikkelsen, K. V. Assessment of binding energies of atmospherically relevant clusters. Phys. Chem. Chem. Phys. 2013, 15 (39), 1644216445. 
(67) Elm, J.; Kristensen, K. Basis Set Convergence of the Binding Energies of Strongly Hydrogen-bonded Atmospheric Clusters. Phys. Chem. Chem. Phys. 2017, 19 (2), $1122-$ 1133.

(68) Myllys, N.; Elm, J.; Halonen, R.; Kurtén, T.; Vehkamaki, H. Coupled Cluster Evaluation of the Stability of Atmospheric Acid-Base Clusters with up to 10 Molecules. J. Phy. Chem. A 2016, 120 (4), 621-630.

(69) Riplinger, C.; Sandhoefer, B.; Hansen, A.; Neese, F. Natural Triple Excitations in Local Coupled Cluster Calculations with Pair Natural Orbitals. J. Chem. Phys. 2013, 139 (13), 134101.

(70) Riplinger, C.; Neese, F. An Efficient and Near Linear Scaling Pair Natural Orbital Based Local Coupled Cluster Method. J. Chem. Phys. 2013, 138 (3), 034106.

(71) Kumar, M.; Francisco, J. S. Ion Pair Particles at the Air-water Interface. Proc. Natl. Acad. Sci. U. S. A. 2017, 114 (47), 12401-12406.

(72) Xu, J.; Finlayson-Pitts, B. J.; Gerber, R. B. Proton Transfer in Mixed Clusters of Methanesulfonic Acid, Methylamine, and Oxalic Acid: Implications for Atmospheric Particle Formation. J. Phys. Chem. A 2017, 121 (12), 2377-2385.

(73) Olenius, T.; Kupiainen-Maatta, O.; Ortega, I. K.; Kurtén, T.; Vehkamaki, H. Free Energy Barrier in the Growth of Sulfuric Acid-ammonia and Sulfuric Aciddimethylamine Clusters. J. Chem. Phys. 2013, 139 (8), 084312.

(74) Dal Maso, M.; Hyvarinen, A.; Komppula, M.; Tunved, P.; Kerminen, V. M.; Lihavainen, H.; Viisanen, Y.; Hansson, H. C.; Kulmala, M. Annual and Interannual Variation in Boreal Forest Aerosol Particle Number and Volume Concentration and Their Connection to Particle Formation. Tellus Ser. B-Chem. Phys. Meteorol. 2008, 60 (4), 495-508.

(75) Jayaratne, R.; Pushpawela, B.; He, C. R.; Li, H.; Gao, J.; Chai, F. H.; Morawska, L. Observations of Particles at Their Formation Sizes in Beijing, China. Atmos. Chem. Phys. 2017, 17 (14), 8825-8835.

(76) Qi, X. M.; Ding, A. J.; Nie, W.; Petaja, T.; Kerminen, V. M.; Herrmann, E.; Xie, Y. N.; Zheng, L. F.; Manninen, H.; Aalto, P.; Sun, J. N.; Xu, Z. N.; Chi, X. G.; Huang, X.; Boy, M.; Virkkula, A.; Yang, X. Q.; Fu, C. B.; Kulmala, M. Aerosol Size Distribution and New Particle Formation in the Western Yangtze River Delta of China: 2 Years of Measurements at the SORPES Station. Atmos. Chem. Phys. 2015, 15 (21), 1244512464.

(77) Elm, J. An Atmospheric Cluster Database Consisting of Sulfuric Acid, Bases, Organics, and Water. ACS Omega 2019, 4 (6), 10965-10974.

(78) Schobesberger, S.; Junninen, H.; Bianchi, F.; Lonn, G.; Ehn, M.; Lehtipalo, K.; Dommen, J.; Ehrhart, S.; Ortega, I. K.; Franchin, A.; Nieminen, T.; Riccobono, F.; Hutterli, M.; Duplissy, J.; Almeida, J.; Amorim, A.; Breitenlechner, M.; Downard, A. J.; Dunne, E. M.; Flagan, R. C.; Kajos, M.; Keskinen, H.; Kirkby, J.; Kupc, A.; Kurten, A.; Kurtén, T.; Laaksonen, A.; Mathot, S.; Onnela, A.; Praplan, A. P.; Rondo, L.; Santos, F. D.; Schallhart, S.; Schnitzhofer, R.; Sipila, M.; Tome, A.; Tsagkogeorgas, G.; Vehkamaki, H.; Wimmer, D.; Baltensperger, U.; Carslaw, K. S.; Curtius, J.; Hansel, A.; 
Petaja, T.; Kulmala, M.; Donahue, N. M.; Worsnop, D. R. Molecular understanding of atmospheric particle formation from sulfuric acid and large oxidized organic molecules. Proc. Natl. Acad. Sci. U. S. A. 2013, 110 (43), 17223-17228.

(79) Liu, L.; Kupiainen-Maatta, O.; Zhang, H.; Li, H.; Zhong, J.; Kurtén, T.; Vehkamaki, H.; Zhang, S.; Zhang, Y.; Ge, M.; Zhang, X.; Li, Z. Clustering Mechanism of Oxocarboxylic Acids Involving Hydration Reaction: Implications for the Atmospheric Models. J. Chem. Phys. 2018, 148 (21), 214303.

(80) Henschel, H. Kurtén, T.; Vehkamäki, H. Computational Study on the Effect of Hydration on New Particle Formation in the Sulfuric Acid/Ammonia and Sulfuric Acid/Dimethylamine Systems. J. Phys. Chem. A 2016, 120 (11), 1886-1896.

(81) DePalma, J. W. D., D. J.; Johnston, M. V. Formation and Growth of Molecular Clusters Containing Sulfuric Acid, Water, Ammonia, and Dimethylamine. J. Phys. Chem. A 2014, 118 (29), 5464-5473.

(82) Kurtén, T.; Kuang, C. A.; Gomez, P.; McMurry, P. H.; Vehkamaki, H.; Ortega, I.; Noppel, M.; Kulmala, M. The Role of Cluster Energy Nonaccommodation in Atmospheric Sulfuric Acid Nucleation. J. Chem. Phys. 2010, 132, 024304.

(83) Lin, Y.; Ji, Y. M.; Li, Y. X.; Secrest, J.; Xu, W.; Xu, F.; Wang, Y.; An, T. C.; Zhang, R. Y. Interaction between Succinic Acid and Sulfuric Acid-base Clusters. Atmos. Chem. Phys. 2019, 19 (12), 8003-8019.

(84) Lee, S. H.; Gordon, H.; Yu, H.; Lehtipalo, K.; Haley, R.; Li, Y. X.; Zhang, R. Y. New Particle Formation in the Atmosphere: From Molecular Clusters to Global Climate. J. Geophys. Res.-Atmos. 2019, 124 (13), 7098-7146.

(85) Maergoiz, A. I.; Nikitin, E. E.; Troe, J.; Ushakov, V. G. Classical Trajectory and Adiabatic Channel Study of the Transition from Adiabatic to Sudden Capture Dynamics. III. Dipole-dipole Capture. J. Chem. Phys. 1996, 105 (15), 6277-6284.

(86) Georgievskii, Y.; Klippenstein, S. J. Long-range Transition State Theory. J. Chem. Phys. 2005, 122, 194103.

(87) Duporte, G.; Riva, M.; Parshintsev, J.; Heikkinen, E.; Barreira, L. M. F.; Myllys, N.; Heikkinen, L.; Hartonen, K.; Kulmala, M.; Ehn, M.; Riekkola, M. L. Chemical Characterization of Gas- and Particle-Phase Products from the Ozonolysis of alphaPinene in the Presence of Dimethylamine. Environ. Sci. Technol. 2017, 51 (10), 56025610.

(88) Duporte, G.; Parshintsev, J.; Barreira, L. M.; Hartonen, K.; Kulmala, M.; Riekkola, M. L. Nitrogen-Containing Low Volatile Compounds from PinonaldehydeDimethylamine Reaction in the Atmosphere: A Laboratory and Field Study. Environ. Sci. Technol. 2016, 50 (9), 4693-700. 